\title{
Promotion Activities for Curug Rahong Tourism Village to Boost Tourists Arrival
}

\author{
Retno Dyah Kusumastuti ${ }^{1 *}$, Fathinah Ranggauni Hardy ${ }^{2}$, \\ Muhammad Ikhsan Amar $^{3}$ \\ ${ }^{1}$ Fakultas Ilmu Sosial dan Ilmu Politik Universitas Pembangunan Nasional Veteran, \\ Jakarta 12450, Indonesia \\ ${ }^{23}$ Fakultas Ilmu Kesehatan Universitas Pembangunan Nasional Veteran, Jakarta 12450, Indonesia
}

\begin{abstract}
A B S T R A C T
This study focuses on the promotion activities in Curug Rahong Tourism Village. Curug Rahong Tourism Village is one of the recently established tourism villages that is located in Pandeglang Regency, Province of Banten. The objective of this study is to explore further promotional activities that have been done by Curug Rahong Tourism Village management. This study is a descriptive study with a qualitative approach, and the data for this study was collected using observation, interview, and documentation. This study finds that Curug Rahong Tourism Village promotion activities were carried out using promotional tools in the form of advertisements, word of mouth, and interactive marketing. Curug Rahong Tourism Village Manager advertises using brochures, while interactive marketing is done through websites and a number of social media platforms, namely Facebook and Instagram. As for the implication, this study suggests that it is important for the management of tourism village to utilize the internet as tool of promotion, innovate the offerings to the tourists, and raise the awareness of the local community about the importance of tourism itself.
\end{abstract}

A R T I C L E I N F O

Article History:

Received : 30-05-2020

Revised : 05-10-2020

Accepted : 12-10-2020

Published : 31-10-2020

Keywords:

Promotion

Marketing Communication

Advertising

Word-of-Mouth

Interactive Marketing

*Corresponding Author E-mail:

retnodyah@upnvj.ac.id

Copyright (C) 2020 Authors. This is an open access article distributed under the Creative Commons Attribution License, which permits unrestricted use, distribution, and reproduction in any medium, provided the original work is properly cited.

\section{INTRODUCTION}

A tourism village is a village with unique characteristics, and also has the potentials to be a destination for tourists. The purpose for the tourism village itself is to enable the village to be a tourism object and subject. This means as the object of tourism, the village acts as a tourism destination, while as the subject of tourism, the village acts as an organizer for tourism activity. The success of the tourism village will be directly enjoyed by village inhabitants themselves, 
therefore the active role of the village inhabitants are very important for tourism village sustainability (Hadiwijoyo, 2012).

Banten is one of the provinces in Indonesia with a lot of potential tourism destinations. Aside from its fascinating historic sites, Banten also has very interesting customs from its people, which are very rich with unique historical values (Subali, et al., 2018). Apart from historic site development as a tourism destination, it is also important to develop the potentials of tourism village. Banten actually has a lot of fascinating tourism destinations, especially natural, historic, and cultural sites. However, those destinations mostly still unknown by tourists themselves, and only a few iconic destinations are well-known by tourists. One of the village areas which still has natural landscape and also rich with local cultural values is Cimanggu Village in Pandeglang Regency.

Curug Rahong Tourism Village which is located in Cimanggu Village is one of the tourism villages with a natural view and beautiful scenery, therefore it has the potentials to be developed as a tourism destination. This is because according to our findings, apart from its natural view and beautiful scenery, tourists could also experience the traditions of the village inhabitants, such as rice farming and other crops farming. Tourists could also enjoy the sensation of swimming in the river and taste the local cuisine. If this village could have a reliable promotion strategy, Curug Rahong could compete with other tourism destinations in Banten, and even with other tourism destinations in Indonesia. However, considering that there are numerous tourist destinations in Banten and other provinces in Indonesia as well, this will not be an easy feat. Because of that, we are determined to explore further about Curug Rahong management's promotion strategy.

One of the attempts to develop alternative tourism that could enhance the tourism industry is by catering to the tourists' demands. Nowadays, there are a lot of tourists with unique demands. According to Pitana \& Diarta (2009), tourists with unique demands will be a backbone for tourism industry development in the future. This is because those tourists have already demanded tourism sites which are focus on its offerings and could satisfy tourists' unique demands. This kind of market segment is very pleased with tourism sites that could satisfy their unique needs. This includes Curug Rahong Tourism Village because this village offers a broad variety of product, service, and experience.

Tourism is one of the natural resources that could be developed by every region in Indonesia, and also a a source of foreign exchange for Indonesia. Indonesia is a country with numerous fascinating natural sites, and this country also has a lot of tourists attractions. Apart from a source of foreign exchange, tourism could also play a strategic role in Indonesia's development. Tourism could create a lot of new businesses and new jobs, enhances the welfare of Indonesian's people and increases the government's revenue, supports the preservation and development of national culture, expands the national insight, enables regional development, supports the environmental protection, and raise the patriotism of Indonesian people (Neumeier \& Pollermann, 2014).

With the increasing demand for the tourism industry, Banten actually has a lot of potential tourism destinations that tourists might want to visit. Because of that, it is important to establish and promote the tourism destinations which still unknown to the tourists. This effort should be supported by local inhabitants. Thus, apart from introducing those tourism destinations which still unknown, this effort could also improve income equality and provides business opportunities for local inhabitants (Jianchao, et al., 2015).

The purpose of promotion for Curug Rahong Tourism Village is to attract local and foreign tourists, and also enables this site to compete with other tourism destinations in Indonesia. One of the efforts for promotion is through media social promotion. In this process of promotion, we want to explore further promotional activities 
that have been done by Curug Rahong Tourism Village management.

Curug Rahong is a new tourism destination that has beautiful scenery. Also, according to our findings, this site has a lot of unique characteristics that could be developed as tourists' attractions. The tourists that visited this site could learn more about the village's natural, religious, and cultural aspects with help from a local guide that is provided by Curug Rahong Tourism Village management.

\section{LITERATURE REVIEW}

\section{Tourist}

According to Pitana \& Diarta (2009), the word "tourist" refers to a person. Generally, tourist is a subset or part of traveler or visitor. To be considered as a tourist, someone is has to be either a traveler or a visitor. Every visitor is a traveler, but not every traveler is a tourist. The word "traveler" has a broad meaning, in which it could means somebody that routinely travels to office, school, or other places. However, this people could not be considered as tourist. The difference between travelers and tourists is that the tourists travel out from their normal residence area, while travelers only travel in their normal residence area (Pitana \& Diarta, 2009; Sharpley, 2014). The tourists also travels to interact with other people in other places, and to encounter the local residents culture and lifestyle (Sharpley, 2014).

The tourists is considered as part of "the largest peaceful movement of people" (Lett in Sharpley, 2014), both within one country or across multiple countries. The tourists also contribute as source of income and employment for local residents, alongside as source of foreign exchange and government revenues (Sharpley, 2014). The tourists therefore play important part into economic growth and development in the tourism area (Jenkins in Sharpley, 2014).

\section{Tourism Village}

According to Hadiwijoyo (2012), a tourism village is an area in a village that offers an authentic rural atmosphere both from the aspect of socio- economic and socio-cultural, its customs and the daily life of its local inhabitants, its unique architecture and spatial structure, or its unique and interesting economic activities that has the potential to be developed as various supporting components of tourism, such as:

1. Tourism attraction, which encompasses natural, cultural, and man-made aspects. The tourism attraction must be the most attractive for tourists in that village.

2. Accommodation, which means the distance of the tourism destination from tourists' lodging and the distance of tourism destination from the regency's capital or the province's capital.

3. The village's capacity, which means the number of the house, the number of inhabitants, and the area of that village. This aspect is important to determine the village's capability to serve its tourists.

4. Norms and religious system, which covers specific and unique rules in that village community. Therefore, it is important to consider the main religion and main norms in that community.

5. The infrastructure's readiness, including transportation service, electricity, clean water, drainage, telephone, and other facilities.

The tourism village is an important part of rural tourism (Jianchao, et al., 2015). Therefore, as a part of rural tourism, the tourism village contributes to economic development in the rural area, by providing additional income and employment for local residents. The tourism village also plays role in the protection of rural environment and traditional rural culture (Su, et al., 2011).

\section{Marketing Communication}

According to Kotler \& Keller (2012), marketing communication are "the means by which firms attempt to inform, persuade, and remind consumers-directly or indirectly-about the products and brands they sell". This definition means that marketing communication is a tool to transmit the voice of the firm. With marketing communication, firms could create a dialogue and 
establish a relationship with consumers (Kotler \& Keller, 2012; Keller, 2009).

Every party involve in the marketing communication process does the same way, which is listening, reacting, and speaking until a satisfying exchange relationship is created. The exchange of information, persuading other parties, and negotiation is all part of the marketing communication process. Marketing communication could help to bring together consumers and vendors in an exchange relationship and creates an exchange of information between consumer and vendor, thus enabling a more efficient exchange and guaranteeing every party to reach a satisfying exchange. In marketing, communication initiative could come either from the vendor or consumer. This means the vendor could act as a receiver or sender (Sulaksana, 2007).

For marketing communication, strategic planning is a process to identify problems that could be solved with marketing communication, then establish goals or targets (things that the party needs to achieve), creating a strategy (how to achieve the goals), and implementing the strategy (actions to implement the plan). In dealing with communication problems, planners are faced with a number of problems themselves, especially the limitation of available communication resources, in order to reach the objectives that need to be achieved (Prisgunanto, 2006).

Communication plays an important role for marketers because without communication, consumer society as a whole will not know the existence of the product in the market. Marketing communication requires a hefty budget, therefore marketers must be careful and full of consideration for planning marketing communication. The decision of who the communication target is will greatly determine the success of communication. With the right target, the communication process will run effectively and efficiently (Sulaksana, 2007).

In marketing communication, there is a term that refers to planning in conducting marketing communication activities. The term is referred to as "marketing communication strategy". Marketing communication strategy can be understood by outlining two main elements, namely marketing strategy, and communication. The concept of marketing communication suggests that companies must carefully combine promotional tools and coordinate those tools. Marketing communication tools have unique characteristics. These characteristics include advertising, direct marketing, sales promotion, and interactive marketing (Prisgunanto, 2006).

\section{Promotion}

Promotion is an activity that aims to introduce and inform about a product, in order to attract consumers and persuade the consumers to buy the product. Companies that doing the promotion must determine exactly which promotional tools will be used, in order to achieve success in sales. Promotion itself is considered as an important part in a marketing campaign, since this activity is designed to boost quicker or greater purchase of the products by consumers. This is achieved by offering a collection of incentive tools to consumers (Kotler \& Keller, 2012).

Promotion is a communication from sellers who inform, persuade, and remind potential buyers of a product, in order to influence their opinions or obtain a response (Lamb, Hair, \& McDaniel in Jaiz, 2014). The promotion function is to find and obtain the attention of prospective buyers, create the interest of prospective buyers, and develop the curiosity or desire of prospective buyers to have the product. The purpose of promotion is to inform the new product to the market, explains its benefits, informs about price changes, explains how the product works, describes existing services, improves the image of the product or company, reduces buyer fears, persuades or changes perceptions about the attributes of a product to be accepted by potential buyers, and remind customers and prospective buyers about the product, and maintain awareness of the product (Jaiz, 2014). 
Promotion is also a series of activities carried out by companies to communicate the advantages of their products and persuade customers and consumers to buy their products. The company does a variety of ways to do the promotion, thus the products that have been delivered get a good response from prospective buyers. There are a few tools of promotion, namely advertising, direct marketing, word of mouth, and interactive marketing (Kotler \& Keller, 2012).

\section{Advertising}

According to Sulaksana (2007), advertising is a form of non-personal communication through various mass media, such as TV, radio, magazines, and newspapers, about the information on products and services or ideas of a known sponsor. Based on the above explanation, it can be concluded that advertising is all forms of non-personal presentations intended to promote ideas and provide information about the advantages and benefits of a product. This presentation is sent through the media to get a response from the target market. Advertising itself could be a cost-effective method to spread the company's messages, either to create brand preference or to educate consumers about the company's product (Kotler \& Keller, 2012). There are several common medium of advertising, namely: 1) Television advertising is an advertising with television for its medium. This advertising could reaches a broad spectrum of consumers at low cost per exposure. It could also clearly demonstrate the company's product. However, because of the high volume of television advertising, this advertising could be ignored by the consumers; 2) Print advertising, which is an advertising in printed form (throgh magazine, newspaper, or leaflet), that could communicate more detailed information about the product to the consumers than television advertising. However this advertising is static, thus less dynamic and more passive than television advertising; (3) Radio advertising is an advertising with radio for its medium. This advertising is very targeted since the radio has smaller coverage than television. This advertising strongly depends on audio cues in order to influence the consumers.
Thus, this advertising is lack of visual images, and relatively passive in nature (Kotler \& Keller, 2012).

\section{Direct Marketing}

According to Kotler \& Keller (2012), direct marketing is "the use of consumer-direct channels to reach and deliver goods and services to customers without using marketing middlemen". Direct marketing is a marketing activity that utilizes the use of telephone, internet, fax, or mail. The marketer uses this medium in order to directly reach and communicate with specific consumers (Kotler \& Keller, 2012). There are several mediums of direct marketing, namely: (1) Direct mail, in which the marketers send mail pieces, such as foldouts, letters, and flyers, directly to specific consumers. The marketers sometimes also send DVDs to consumers; (2) Catalog marketing, in which the marketers send product catalogs to the consumers, either in printed form, in DVDs, or through e-mail; (3) Telemarketing, in which the marketers utilizes the telephone and call centers to reach specific consumers; (4) Infomercials, is a television commercials which are tailored for direct marketing. Because of that, this commercials is longer than normal television commercials, thus could explain more about the product.

\section{Word of Mouth}

According to Schiffman \& Wisenblit (2015), word of mouth is "an oral or written communication in which satisfied or dissatisfied customers tell others how much they like or hate a business, product, service, or event". Satisfied customers would create positive word of mouth, while dissatisfied customers would create negative word of mouth. In positive word of mouth, satisified customers communicate their satisfaction and like of the product to other people, whereas in negative word of mouth, dissatisfied customers communicate their dissatisfaction and hate of the product to other people (Schiffman \& Wisenblit, 2015; East, Hammond, Lomax, 2008). Word of mouth plays important role in shaping the attitude of the consumers towards a product. This is because 
the customers that transmit the word of mouth is considered as highly credible by other consumers, since those customers do not earn anything by doing the word of mouth activity. Thus, those customers would be seen as neutral, unlike the marketers from a company. Because the perceived high credibility of the word of mouth activity, it could be said that word of mouth is the best advertising. Word of mouth also has strong influence to consumers behavior, especially in buying behavior (Schiffman \& Wisenblit, 2015).

\section{Interactive Marketing}

According to Shankar \& Malthouse (2007), interactive marketing is "an integrated exchange process by which an organization uses the understanding of customer behavior, technology, and other resources to create and manage customer value and collaborative relationships and enhance shareholder value through relevant brands, products or service offerings, ideas, and messages communicated and delivered to the right customers through appropriate channels and contact points at appropriate times". Nowadays, in an increasingly digital era, the world seems to be entirely accessible with one gadget screen. Interactive marketing is more aimed at how a company is able to communicate with its customers, or able to provide a good solution related to the use of its products. Marketing activities are carried out interactively through several mediums, namely: (1) Web sites, in which the company interacts with consumers through its website; (2) Search ads, in which the company utilizes the search engines (Google, Yahoo!, Bing) to place its advertising; (3) Display ads or banner ads, in which the company place its advertising in other web sites. This advertising usually is a small, rectangular boxes that contains information about the product; (4) E-mail, in which the company inform and communicate the product to specific consumers through e-mail; (5) Mobile marketing, in which the company reach and communicate to the consumers through their smartphone. Mobile marketing could use SMS text messages or mobile apps to convey its messages (Kotler \& Keller, 2012).

\section{METHODS}

This study was performed from August 2019, until January 2020. In this study, researchers chose to use qualitative methods. In qualitative method, the researchers would focus on the analysis of data and information that are descriptive in nature and not readily quantifiable (Sekaran \& Bougie, 2010). Because of its exploratory in nature, the researcher chose the qualitative method. Thus, the researchers could find out more about how the process and promotional activities were carried out by the management of the Curug Rahong Tourism Village (Sekaran \& Bougie, 2010). Considering this research is a qualitative study, the data obtained in this study are in the form of soft data, namely in words and images (Neuman, 2014). The data comes from interview scripts, field notes, photos, videos, personal documents, notes or memos, and other official documents. To analyze the data in this study, the researchers applied a descriptive method. The descriptive method is a method that is applied in order to discover and describe the characteristics of the research object (Sekaran \& Bougie, 2010). Therefore, the researchers aim to make a systematic, factual, and accurate description about promotional activities that was carried out by the management of Curug Rahong Tourism Village.

In this study, researchers will use two data collection techniques, namely observation and interviews. Observation is a data collection method in which the researchers observing people or events in the work environment and recording the information, while interview is a data collection method in which the researchers asks for information verbally from the respondents (Sekaran \& Bougie, 2010). Researchers made observations about the potential of tourism products in the village, access to the tourist village, the location of the tourist village, and the facilities and infrastructure in the village. Interviews were conducted with respondents to provide specific information regarding the promotion activities of Curug Rahong Tourism Village. The researchers conducted the structured interviews, in which the researchers list every 
questions that will be asked to the respondents (Yin, 2016). In this interview, the researchers has no control over the answers of the respondents, therefore the respondents are free to provide answers. The research's respondents that were chosen for this study are: (1) Mr. Yayat Supiyat (Head of Cimanggu Village); (2) Mr. Gojim (Manager of Curug Rahong Tourism Village); (3) Syafira (Tourists in Curug Rahong Tourism Village). To complete the data from observations and interviews, the documentation data was also collected from the internet and books.

After conducting research and obtained data, the data will be analyzed in order to find a description of the promotion activities of Curug Rahong Tourism Village. This study uses the analysis method from Miles and Haberman model (Miles and Haberman in Sugiyono 2012). There are three stages used in the process of processing and analyzing qualitative data, namely: (1) Data reduction, in which the data that has been collected will be coded according to their similarities and dissimilarities; (2) Data presentation, in which the data will be presented in the form of research narrative; (3) Conclusions withdrawal and verification, in which the researchers present the conclusion of the research and verify the findings with triangulation techniques (Yin, 2016; Suyanto, 2018). To ensure the validity of the data, researchers used triangulation techniques. Triangulation is a technique in which the researchers would take multiple measures to study the same phenomenon. The researchers would applied two kinds of triangulation, namely: (1) the triangulation of method, in which the researchers would compare the observational data with the interview data; (2) the triangulation of data, in which the researchers would collect data from several resources (informants) and compare them (Neuman, 2014; Sekaran \& Bougie, 2010).

\section{RESULTS AND DISCUSSIONS}

Profile of Curug Rahong Tourism Village

Curug Rahong Tourism Village is located in Cimanggu Village, Cimanggu District, Pandeglang Regency, Province of Banten. Curug Rahong
Tourism Village is located 208 kilometers from Jakarta, or about 4.5 hours driving. The main attraction of this tourism village is Curug Rahong. Curug Rahong is a natural waterfall located in southern part of Cimanggu Village. The existence of Curug Rahong Tourism Village is fairly new. This is according to Mr. Yayat Supiyat (Head of Cimanggu Village).

Q: "Why the Curug Rahong Tourism Village was established in this village?"

A: "At first I was very concerned to see that many inhabitants here still did not know about the natural potential. Then I thought to make this village as an object of tourism, therefore it can be seen that there is a lot of natural potential in this village that could be utilized as an object of tourism if managed properly. It is not easy to make this village a tourism village, since not everybody supports it. However, we do it repeatedly so that the inhabitants could understand and accept" (Mr. Yayat Supiat, the Head of Cimanggu Village, November 7th, 2019).

Since then, the Curong Rahong Tourism Village in Banten has continued to develop until now. Since in the early time of Curug Rahong Tourism Village, this tourism village offers a rural life with nature tourism. However, until now it is unfortunate that Curug Rahong Tourism Village has not gained the attention or support from the local government itself.

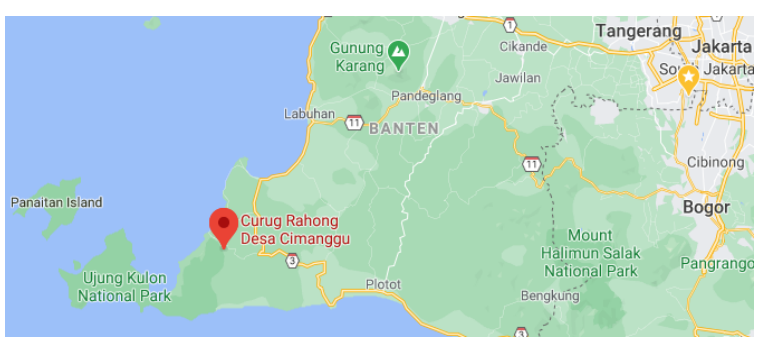

Table 1. Location of Curug Rahong Tourism Village

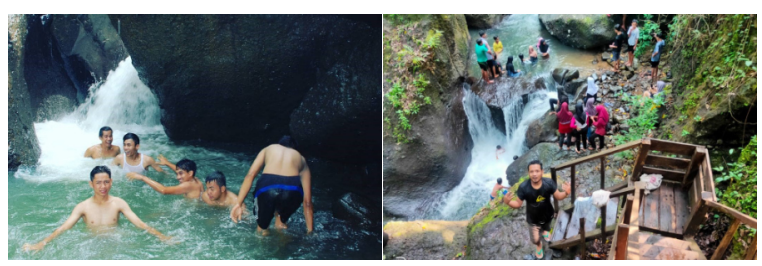

Table 2. Curug Rahong 


\section{The Potentials of Curug Rahong Tourism Village}

To develop a tourism destination, it is very important to know the potential of that tourism destination to attract tourists, such as natural beauty and natural potential. Therefore, it is very important to know the potential possessed by the tourism destination before making further development, in order to optimize the potential of that tourism destination.

Observations and interviews were conducted with key respondents and other respondents by researchers, with the aim of gathering information about the potential of the Curug Rahong Tourism Village. The results of these interviews and observations is this village has a few potentials, namely a very beautiful rural environment, its local wisdom, and its social culture. According to Mr. Yayat Supiat:

Q: "What are the potentials of the Curug Rahong Tourism Village?"

A: "Besides its potentials in educational tourism and natural tourism, Curug Rahong Tourism Village also has a place that I think is very potential to be developed, such as the river that could be used as a swimming area. This is possible if the community can work together to protect and not litter in the river, so the river will look very beautiful" (Mr. Yayat Supiat, the head of Cimanggu Village, November 6th 2019).

From the results of the interview above, researchers found that the Curug Rahong Tourism Village has the potentials to attract tourists in the form of socio-cultural tourism. Besides that, Curug Rahong Tourism Village also has other types of tourism, namely natural tourism. One of the natural tourism which is offered by Curug Rahong Tourism Village is tracking for tourists who like to explore the village. The tourists will be accompanied by a guide that has been prepared by the management. The tourists will be able to enjoy the rural atmosphere, and also could see the daily life of local inhabitants. The tourists could also walk through the forest in the Ujung Kulon
National Park area.

In addition to the types of tours offered by the management of Curug Rahong Tourism Village, researchers also collected information about the facilities for tourists in the Curug Rahong Tourism Village with the observation method. The facilities which are available are as follows:

1. Access Road to Curug Rahong Tourism Village Access to the Curug Rahong Tourism Village area is still unpaved, which starts from the welcome gate to the area of Curug Rahong Tourism. Tourists could travel around the Curug Rahong Tourism Village on foot.

2. Treehouse

Curug Rahong Tourism Village also has a treehouse to accommodate the tourists that want to stay a little longer in Curug Rahong Tourism Village.

There is also other potential tourist attractions that could be developed in Curug Rahong Tourism Village, namely the socio-cultural community in the Curug Rahong Tourism Village. According to one of the tourists (Mrs. Syafira):

Q: "What are the things that you experienced during your visit in this tourism village?"

A: "Yesterday, when I visited the Curug Rahong Tourism Village since I am not fluent in Sundanese, I talked in Indonesian instead. Coincidentally, there was also a village community that produced emping (chips from Gnetum gnemon), so that I could learn how to make the chips. I found out that they used sand to cook the chips, so I get new knowledge and new experiences" (Mrs. Syafira, a tourist visiting Curug Rahong Tourism Village).

According to the results of the interview above, Curug Rahong Tourism Village has the sociocultural potential of the village community, which can be developed and managed as an attraction for tourists. 


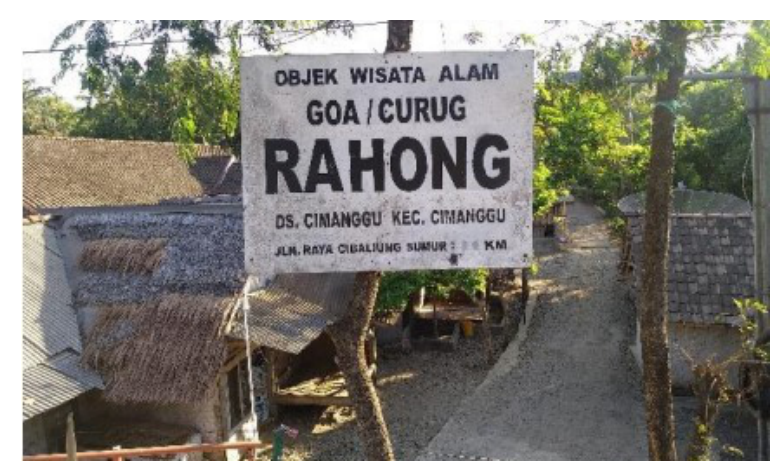

Table 3. Access Road to Curug Rahong Tourism Village

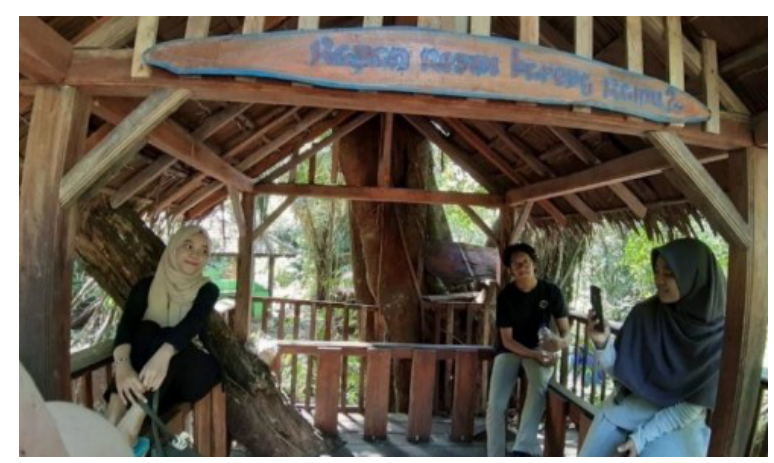

Table 4. Treehouse in Curug Rahong Tourism Village

\section{Curug Rahong Promotion Methods and Limitations}

The management of Curug Rahong Tourism Village has promoted its village through advertising. Advertising activities are very important for Curug Rahong Tourism Village to introduce the village to the wider communities, especially to tourists. With advertising, it is hoped that the village could gain the tourists' attention, and attract more tourists to visit this tourism village. As stated by Mr. Yayat Supiat:

Q: "How do you promote this tourism village to tourists?"

A: "We made brochures in the early days of this tourism village to inform the tourists about this tourism village" (Mr. Yayat Supiat, the head of Cimanggu Village, November 6th 2019).

From the interview results above, it is found that the management of Curug Rahong Tourism Village used advertisements in the form of print media, specifically a brochure. Brochures were created by the management of Curug Rahong Tourism Village to facilitate the potential tourists to find out more information about Curug Rahong Tourism Village. The brochure contains pictures of the beauty and natural scenery of Curug Rahong, alongside the invitations to visit the Curug Rahong Tourism Village, and information about the contact person, social media accounts, and the managers' addresses. With those information, tourists could find out more about Curug Rahong Tourism Village.

In addition to using brochures, the promotion of Curug Rahong Tourism Village is also done by using the word-of-mouth. As stated by Mr. Gojim (Member of Curug Rahong Tourism Village Management):

Q: "How do you promote this tourism village to tourists?"

A: "Sometimes I was invited by the Ministry of Tourism to attend a tourism event. In those events, I like to promote Curug Rahong Tourism Village to other friends who also come to that events. I sometimes also ask the event committee to display the promotional video of Curug Rahong Tourism Village and the event committee before the event starts. This means I could get free advertisements for Curug Rahong Tourism Village" (Mr. Gojim, member of Curug Rahong Tourism Village management, November 9th, 2019).

From the results of the interviews above, the word-of-mouth strategy was utilized towards friends and relations. In carrying out the word-ofmouth marketing communication strategy, the management usually tells about the charm and the natural beauty of Curug Rahong Tourism Village to friends that attend the tourism event. The management of Curug Rahong Tourism Village also asks the event committee to display the promotional video that contains about the beauty of Curug Rahong Tourism Village, before the event began.

For interactive marketing, the management of Curug Rahong Tourism Village uses a website (http://cimanggu.haidesa.com). This website contains a lot of information about Curug Rahong 
Tourism Village that the tourists can access, such as the village's location and the contact person's phone number. The management of Curug Rahong Tourism Village used to use an older website. That website contains a photo of Curug Rahong Tourism Village and several articles about Curug Rahong Tourism Village. Those articles discuss a number of things, such as activities that tourists could do if they visit the Curug Rahong Tourism Village. However, currently, the older website is no longer active, and the last post in that website was posted in June 2017.

In addition to the website, Curug Rahong Tourism Village also uses a Facebook account and Instagram account to promote Curug Rahong Tourism Village. In its Facebook account, the manager of Curug Rahong Tourism Village uploaded many photos of tourists visiting the Curug Rahong Tourism Village, ranging from local tourists to foreign tourists. Unlike the website, the Curug Rahong Tourism Village management routinely updates the account's status and upload photos in that account. The last post of the Facebook account itself was done in November 2019.

For Instagram account, the management usually uploads photos of the beauty of Curug Rahong and photos of tourists that visit the village. The management also uses various hashtags, such as \#explorepandeglang, \#visitbanten, \#visitpandeglang, and \#explorebanten. The hashtags are used to group the photos that were uploaded, therefore the photos could more easily be found by tourists. The management itself used the Instagram account more to promote Curug Rahong Tourism Village.

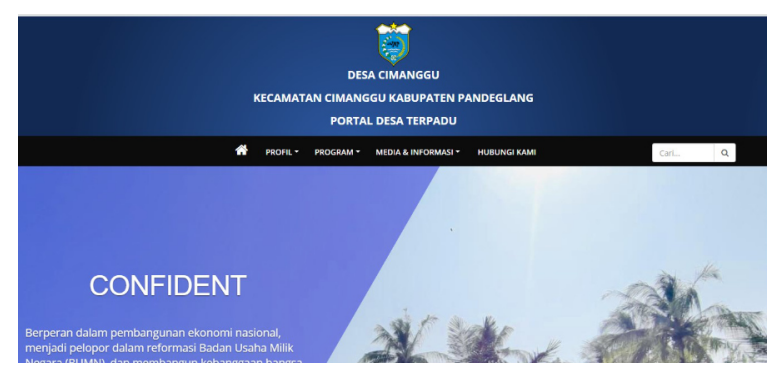

Table 5. Curug Rahong Tourism Village Website

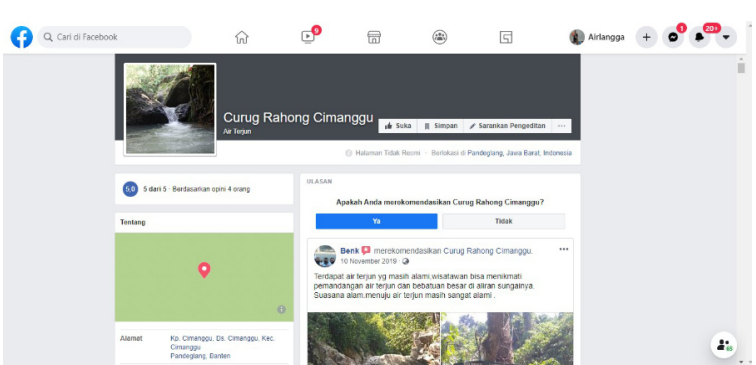

Table 6. Curug Rahong Tourism Village Facebook Account

The Curug Rahong Tourism Village promotion effort is faced with a couple of obstacles. There are two obstacles that occur in the Curug Rahong Tourism Village promotion activities, namely on human resources and on the availability of facilities and infrastructure. The obstacle of human resources lies in the lack of human resources to manage the promotion in social media platforms. According to Mr. Yayat Supiat:

Q: "What are the challenges to promote this tourism village?"

A: "Our obstacle is the lack of employees here for managing (the promotion), so it's okay to do it by myself. I want the young people here to build Curug Rahong Tourism Village to be more developed, but the young people here are working in the factories in the cities instead" (Yayat Supiat, Head of Cimanggu Village, November 9th, 2019).

As stated by Mr. Yayat Supiat, the lack of human resources is due to a large number of village youth who do not care about the natural potential of the Curug Rahong Tourism Village. The lack of availability of facilities and infrastructure also occurs due to the lack of local government attention to develop the Curug Rahong Tourism Village. According to Mr Yayat Supiat:

Q: "Are there any other challenges to promote this tourism village?"

A: "Here all of the many opportunities lay clear. If the village administration wants, souvenir outlets, parking spots, local cuisine, enchanting nature, everything is available. All that is needed is an aid in the form of capital from the village administration" (Yayat Supiat, the person in charge of Curug Rahong Tourism 
Village, November 9th, 2019).

\section{CONCLUSION}

Based on the results of information gathering and analysis that was conducted on the promotion of Curug Rahong Tourism Village, the researcher obtained a number of findings. Researchers found that Curug Rahong Tourism Village promotion activities were carried out using promotional tools in the form of advertisements, word of mouth, and interactive marketing. Curug Rahong Tourism Village Manager advertises using brochures, while interactive marketing is done through websites and a number of social media platforms, namely Facebook and Instagram. The researcher also found that the factors that hindered the process of promotion activities of Curug Rahong Tourism Village were the lack of human resources to manage the promotion of Curug Rahong Tourism Village, and the lack of local government attention as well. This is caused by a lot of village youths who do not care about the natural potential of the Curug Rahong Tourism Village.

Based on these findings, researchers can provide a number of recommendations. For future research on marketing communication, specifically the promotion activities of Curug Rahong Tourism Village, it is better for future research to be more specific and in-depth about the promotional concepts that are used in the promotion activities. Further research is also expected to find a more effective process of promotional activities for tourism villages. In addition, future research is expected to be able to promote the latest tourism program and discuss more deeply about marketing communications, therefore the latest tourism program can be known by national and international tourists.

Researchers also gave a number of recommendations for the Manager of Curug Rahong Tourism Village. Researchers suggest that the Curug Rahong Tourism Village Manager to be more active in utilizing the means of marketing promotion activities via the internet, bearing in mind that the internet is currently more widely used by tourists and is able to reach more tourists also. The manager of Curug Rahong Tourism Village should also innovate in the packaging of facilities and infrastructure available in order to attract more tourists' visits. The Curug Rahong Tourism Village Manager can also provide more diverse types of tourism, making it different from other tourism villages. It is also important for the Manager of Curug Rahong Tourism Village to make the local community more aware of the importance of tourism, thus enabling the community to support the progress of the Curug Rahong Tourism Village.

\section{REFEREN CES}

East, R., Hammond, K., \& Lomax, W. (2008). Measuring The Impact of Positive and Negative Word of Mouth on Brand Purchase Probability. International Journal of Research in Marketing, 25, 215224.

Hadiwijoyo, S. S. (2012). Perencanaan Pariwisata Perdesaan Berbasis Masyarakat: Sebuah Pendekatan Konsep. Yogyakarta: Graha Ilmu.

Jaiz, M. (2014). Dasar-Dasar Periklanan. Yogyakarta: Graha Ilmu.

Jianchao, X., Xinge, W., Qingin, K., \& Nan, Z. (2015). Spatial Morphology Evolution of Rural Settlements Induced By Tourism: A Comparative Study of Three Villages in Yesanpo Tourism Area, China. Journal of Geographical Sciences, 25(4), 497-511.

Keller, K. L. (2009). Building Strong Brands In A Modern Marketing Communications Environment. Journal of Marketing Communications, 15(2-3), 139-155.

Kotler, P., \& Keller, K. L. (2012). Marketing Management. New Jersey: Pearson Education, Inc. 
Neuman, W. L. (2014). Social Research Methods: Qualitative and Quantitative Approaches. Essex: Pearson Education Limited.

Neumeier, S., \& Pollermann, K. (2014). Rural Tourism As Promoter of Rural Development - Prospects and Limitations: Case Study Findings From A Pilot Project Promoting Village Tourism. European Countryside, 4, 270-296.

Pitana, I G., \& Diarta, I. K. S. (2009). Pengantar Ilmu Pariwisata. Yogyakarta: Andi.

Prisgunanto, I. (2006). Komunikasi Pemasaran Strategi \& Taktik. Bogor: Ghalia Indonesia.

Schiffman, L. G., \& Wisenblit, J. L. (2015). Consumer Behavior. Essex: Pearson Education Limited.

Sekaran, U., \& Bougie, R. (2010). Research Methods for Business: A Skill Building Approach. West Sussex: John Wiley \& Sons Ltd.

Shankar, V., \& Edward M. (2007). The Growth of Interactions and Dialogs and in Interactive Marketing. Journal of Interactive Marketing, 21 (2), 2-4.

Sharpley, R. (2014). Host Perceptions of Tourism: A Review of The Research. Tourism Management, 42, $37-49$.

Su, S., Jiang, Z. , \& Zhang, Q. (2011). Transformation of Agricultural Landscapes Under Rapid Urbanization: A Threat To Sustainability in Hang-Jia-Hu Region, China. Applied Geography, 31(2): 439-449.

Subali, M., Andriansyah, M., Saptono, D., Purwanto, I., Antonius, I. S., Rahmadi, H., \& Sudjono, L. A. L. (2018). Development of Banten E-Heritage Using Virtual Reality Technology on Mobile Device. Paper presented at the Third International Conference on Informatics and Computing (ICIC).

Sugiyono. (2009). Memahami Penelitian Kualitatif. Bandung: Alfabeta.

Suyanto. (2018). Analisis Data Kualitatif. In Hartono, J (Ed.) Metode Pengumpulan dan Teknik Analisis Data, pp. 293-316. Yogyakarta: Penerbit ANDI.

Sulaksana, U. (2007). Integrated Marketing Communication. Yogyakarta: Pustaka Pelajar.

Yin, R. K. (2016). Qualitative Research From Start to Finish. New York: The Guilford Press.

\section{A PE N D I X}

Table 1. Table of Informants

\begin{tabular}{ccc}
\hline No & Informant & Role \\
\hline 1 & Mr. Yayat Supiyat & Head of Cimanggu Village \\
\hline 2 & Mr. Gojim & Manager of Curug Rahong Tourism Village \\
\hline 3 & Mrs. Syafira & Tourist \\
\hline
\end{tabular}

Table 2. Table of Coding

\begin{tabular}{ccc}
\hline No & Initial Code & Category Code \\
\hline 1 & History of Curug Rahong & Profile of Curug Rahong \\
\hline 2 & Potentials of Curug Rahong & Profile of Curug Rahong \\
\hline 3 & Tourist's Experience in Curug Rahong & Profile of Curug Rahong \\
\hline 4 & Promotion of Curug Rahong & Marketing of Curug Rahong \\
\hline 5 & Challenges of Curug Rahong Promotion & Marketing of Curug Rahong \\
\hline
\end{tabular}

